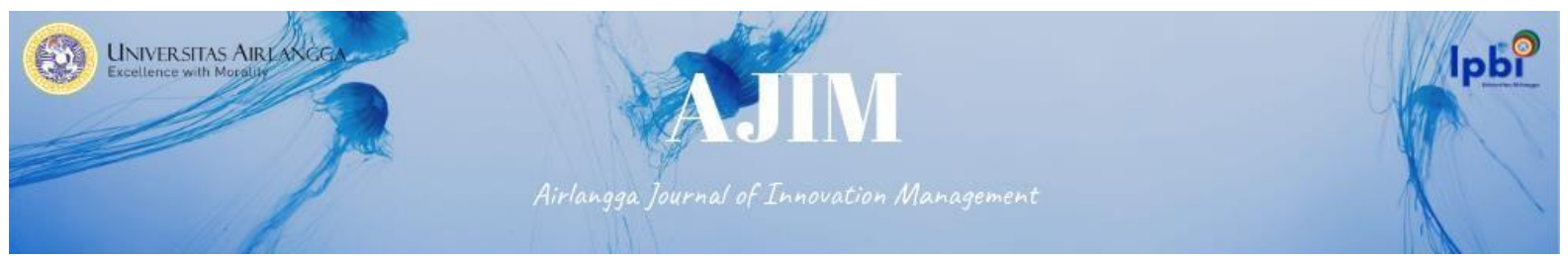

Vol. 2 No.1 Juni 2021

e-ISSN: 2722-5062

DOI : 10.20473/ajim.vvii.26627

\title{
THE EFFECT OF CUSTOMER SATISFACTION AND BRAND EQUITY ON THE INTEREST IN REPURCHASING SUGAR
}

\author{
Ringgo Ismoyo Buwono ${ }^{a}$, Garnet Filemon ${ }^{\mathrm{b}}$, Tri Wisudawatic, Wahyu Adhi Saputro ${ }^{\mathrm{d}}{ }^{*}$ \\ a,b,c Industrial Enginering Study Program, Faculty of Sains and Technology, Duta Bangsa \\ Surakarta University \\ ${ }^{\mathrm{d}}$ Agribusines Study Program, Faculty of Sains and Technology, Duta Bangsa Surakarta \\ University \\ *Corresponding e-mail : wahyuadhi@udb.ac.id
}

\begin{abstract}
Currently, consumer goods business in Indonesia is very strict, including sugar products. Until now, sugar products cannot be fully replaced by other products. The purpose of this study was to determine the effect of customer satisfaction and brand equity on interest in repurchasing sugar products. This study used a descriptive analytic method using two data sources, namely primary data and secondary data. Primary data obtained by interviewing consumers who consume sugar as many as 60 people. Secondary data obtained from data sourced on internet, books, journals and other sources deemed relevant. Analysis of data used in this study is multiple linear regression with dependent variable repurchase interest and two independent variables, namely customer satisfaction and brand equity. Based on research results, it is known that significance value of $F$ test is 0.000 so that value is less than $5 \%$ alpha. Thus it can be said together that variables of customer satisfaction and brand equity have an effect on interest in repurchasing sugar. Based on results of t-test, it can be seen that variable X1 (customer satisfaction) has a significance value of 0.0007 so that value is less than alpha 0.05 in other words that the variable X1 (customer satisfaction) affects interest in repurchasing. Variable X2 (brand equity) has a significance value of 0.0317 so that the value is less than alpha 0.05 , in other words that $\mathrm{X} 2$ variable (brand equity) affects repurchase interest. That way the company's management must be able to maintain customer satisfaction and brand equity that is already good and even increase it. Basically brand equity will be able to increase customer satisfaction and high on repurchase interest made by consumers of a product.
\end{abstract}

Keywords: Sugar, Customer Satisfaction, Brand Equity, Repurchase Interest

\section{Introduction}

Currently existing businesses in Indonesia have very fierce competition, especially on product selling power of each company. Company management will definitely try hard to improve and compete with each other so that products being sold continue to exist in business world. Easier internet access, supported by very fast development of information technology, has made many company management take advantage of this opportunity to attract more consumers (Ishak, 2012). Sale and purchase of goods and services is a reflection of consumer behavior. Consumers certainly will not want to be disappointed with purchase of a product so that consumers are very careful and do not want to be wrong when 


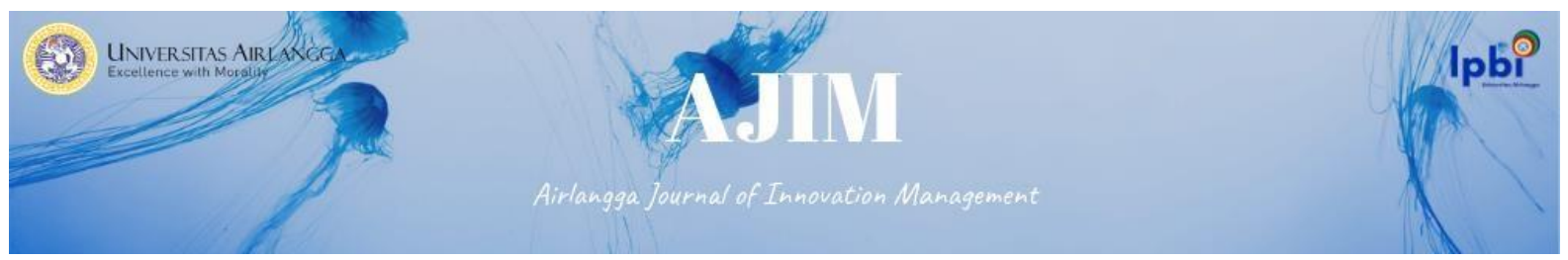

purchasing a product or service. Consumers of course have different behaviors so that in making purchasing decisions, basic things are needed. Consumers often consider various aspects before making a purchase (Ardianto, 2013).

Concept of repurchasing interest carried out by consumers is part of consumer behavior that leads to concept of loyalty. Consumers who are interested in buying a product certainly see a product as a need and are based on intention to buy it. Customer satisfaction arises from result of a sense of satisfaction after purchasing goods and then using them. There are many indicators that can be used in operationalizing consumer satisfaction with products they use, one of which is interest in repurchasing (Wen, 2011) (Casalo, 2011).

The symbol that is represented as a name is referred to as a brand. A brand attached to a product or service will make consumers always remember product or service. Basically, a product or service that already has a brand will benefit in form of added value to product or service so that it has an impact on different selling prices and even higher (Farida, 2014). Brand equity is one of advantages for a product or service because this the product to acquire a strategic market position so that both old and new consumers will find it easier to believe in brand they will buy (Tjiptono, 2011). The existence of this will also create a sense of trust that ends in a relationship between product brand and buyer so as to encourage purchasing preferences and reduce risk to goods purchased. Customers who do or consume a product due to brand equity will certainly be guaranteed satisfaction while in a market system that satisfaction will create a relationship between service providers and customers. Effective performance management must be supported by effective leadership, a culture that focuses on improving performance, engaging communication with stakeholders and feedback for organizational learning (Kurniawati and Sidiq, 2020).

The relationship in marketing system is one of keys to provider channel with buyer which leads to customer satisfaction (Fatona, 2010). Concept of satisfaction indicators can be translated into four parts, namely product attribute performance satisfaction, customer satisfaction arising from benefits of purchased product, customer satisfaction arising from product quality and satisfaction due to product performance (Ferdinand, 2013). Consumers who make repeat purchases can be interpreted as reflecting attitudes and behaviors in which consumer buys product he wants more than once purchase frequency. New consumers who buy product for first time will definitely evaluate product so that a conclusion appears that they are satisfied or dissatisfied with goods purchased. If consumer expresses dissatisfaction with goods purchased, consumer will definitely move to another brand, whereas on other hand, if consumer is satisfied with product or on a certain brand, consumer will repurchase in next period

In general, consumers who want to purchase goods and services aim at fulfilling their daily wants and needs. Consumers usually prioritize purchases of primary needs such as food, clothing and shelter first. But keep in mind that main need which is very important and main thing is need for food. The problem is that need for food that must be fulfilled encourages other individuals to open a business in this field, especially in food and beverage business so that competition in this field is quite tight (Putri, 2016). This competition will also lead many companies to maintain business stability by retaining their existing customers (Ksudyah, 2012). One of companies in question is PT. Sugar Group Companies with their Gulaku products.

Sugar is one of ingredients of nine staple products. Benefit of sugar is as a sweetener which until now has not been replaced by other products. Sugar is also beneficial for energy / calorie intake in body so that sugar is a product that is often purchased by consumers. One of famous sugar brands in 


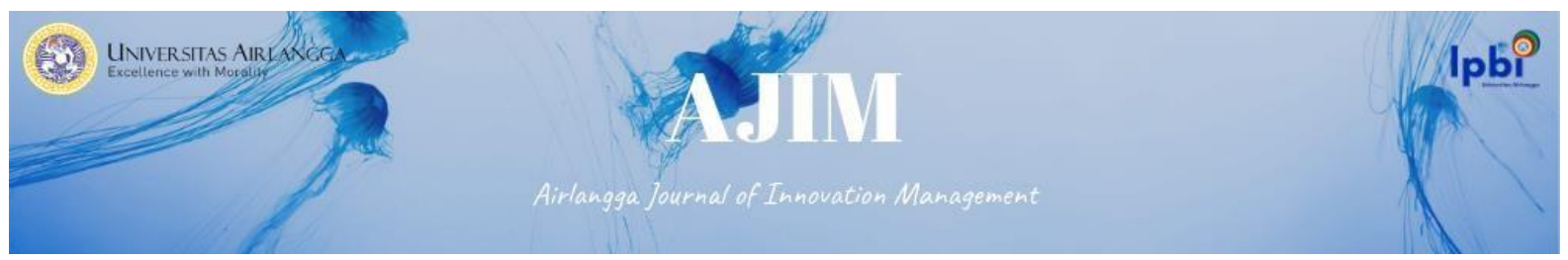

consumers eyes is Gulaku. Based on this description, this study aims to determine effect of customer satisfaction and brand equity on interest in repurchasing Gulaku.

\section{Literature Review}

The influence of information from the use of products or services carried out by others and then recommended to individuals is an effective process in the field of product marketing. This information will certainly affect other people in making the final decision to buy (Solichin et al, 2021). Marketing implementation basically has to prioritize seven important parts such as quality products, relatively affordable selling prices of goods, good and strategic sales locations, promotions with discounts and price discounts, good service or service, sales via online platforms and product displays. interesting (Wisudawati and Rizalmi, 2020). Indonesia is a country that is a potential market due to its large population and tends to be consumptive. This is an opportunity for entrepreneurs to market their products. Increasing demand will also increase profits for the company. However, it is necessary to prioritize the needs and satisfaction of consumers (Sulistyowati et al., 2020).

The development of innovation and technology will of course also make company management more flexible to map their market segmentation so that more products are sold (Ristanto et al, 2021). Company management should also make full efforts in determining the right marketing strategy for the action of developing products that are tailored to clear budgets and procedures. This is known as strategy implementation. These efforts are needed and must be realized so that the product can survive the sales competition (Utomo et al, 2021). The hope of this will certainly increase people's purchasing power of products available in the industrial sector (Katniati, 2021).

\section{Repurchase Interests}

Consumer repurchase interest can be seen from the experience of consumers who have bought products in the past. Repurchase interest is the attitude of consumers who want and tend to buy repeatedly in a certain period based on past experience when using the product (Kusdyah, 2012). Repurchase interest is determined by several factors that influence it, such as customer satisfaction, service quality, brand, physical environment, perceived value, price and product quality (Joseph, et al., 2012) (Awi \& Chaipoopirutana, 2014) (Pupuani \& Sulistyawati, 2013).

\section{Customer satisfaction}

Satisfaction arises from feelings of pleasure and even disappointment from within consumers by considering the expectations of the products they consume. The company is said to be successful if it has a large number of customers so that it will be directly proportional to the product to be sold without neglecting customer satisfaction which must be maintained continuously. Satisfied customers will create a harmonious relationship between consumers and producers so that this will have an impact on consumer repurchases (Kotler, 2009). In fact, the positive effect of these customers will understand satisfaction when consuming these goods, making it easier for company management to carry out unpaid promotions.

Customer satisfaction is also defined as a state of consumer expectations that are materialized and then accepted by consumers with appropriate and maximum service. This is related to the services needed by consumers. Company services below consumer expectations will lead to feelings of disappointment and reluctance to use these services again. However, the opposite applies if the service is the same or even more than consumer expectations, one day the consumer will inform his colleagues so that it can be used as company advertisements (Panjaitan and Yulianti, 2016). Customer satisfaction needs to be prioritized by companies and business people in order to strengthen the purchasing power of consumers towards customers (Wisudawati and Saputro, 2020). Consumers who already know the 


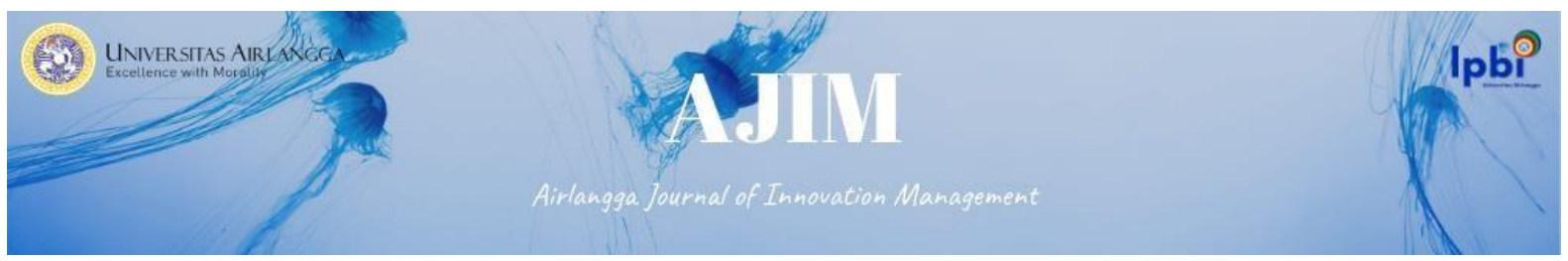

product to be purchased based on experience and advantages in using the product will make repeat purchases (Dewati and Saputro, 2020).

\section{Brand Equity}

Basically, consumers have their own preferences in determining which products they buy. However, it is not uncommon for these preferences to have a preference for a brand of product or service that consumer wants. Consumers tend to buy products in brands they usually use compared to other brands or new brands. Good company management will certainly maintain position of brand or brand that is already attached to its consumers so that it is able to compete with other brands that are major competitors (Halim et al., 2014). Dimensions of brand equity can be classified into four dimensions, namely brand awareness, perceived quality, association and loyalty. Basically, consumers definitely want maximum satisfaction when using certain goods or services with minimal costs adjusted to the limited knowledge and income of these consumers. That way, of course, consumers have hopes or expectations in assessing a product. Brands in products that can maintain quality and consumer expectations will exist in the market (Farida, 2014).

\section{Methods/Materials}

The research was conducted using a descriptive analytic method. This study uses secondary data and primary data. Secondary data is obtained from relevant sources such as books, journals and internet. Primary data using interviews with a questionnaire to sugar buyers. Respondents in this study are consumers who shop at several supermarkets in DIY. Sample selection was carried out by incidental sampling within 60 people. Data analysis used in this research is multiple linear regression analysis. This study uses one dependent variable and two independent variables. Dependent variable in this study is repurchase interest, while independent variables used in this study are customer satisfaction and brand equity. Of course, before entering data multiple regression analysis, first normality test and classical assumption test were carried out. Parameter value will then be estimated so that the model becomes:

$\mathrm{Y}=\alpha 0+\beta 1 \mathrm{X} 1+\beta 2 \mathrm{X} 2+\mathrm{e}$

Information :

$\mathrm{Y}=$ Repurchase

$\alpha 0 \quad=$ Intercept

$\beta 1-\beta 2=$ Coefficient Regression

$\mathrm{e} \quad=$ error term (residual)

$\mathrm{X} 1=$ Customers Satisfaction

$\mathrm{X} 2=$ Brand Equity

The following describes the graph of the relationship between variables in this study.

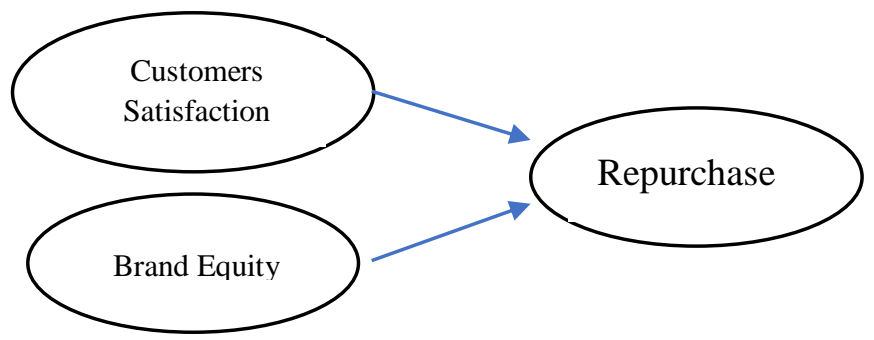

Figure 1. research framework 


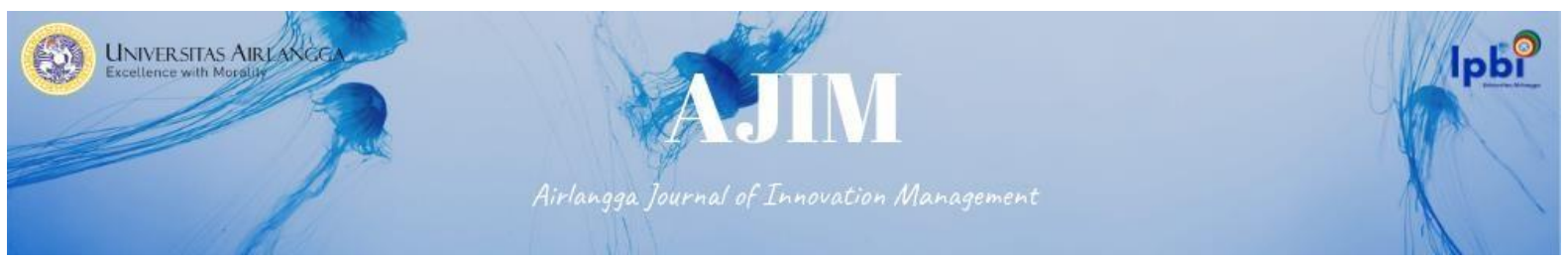

Based on the framework of thought in Figure 1, several hypotheses can be drawn as follows. First, the effect of customer satisfaction on repurchase. obtained by a consumer, can encourage repeat purchases, become loyal to the product or loyal to the store where they bought the item so that consumers can tell good things to others. research from Imran (2018) shows that there is a positive and significant influence between customer interactions on repurchase interest. New competition that has sprung up between products is even possible for new products that have strong competitiveness. So that there must be changes so as not to lose in the competition, one thing that must be considered is customer satisfaction. If these factors can be obtained by the customer, then there will be repurchase interest. Customer satisfaction will affect the power level of customer repurchase interest, it will affect the productivity of the company itself.Based on the description that has been explained previously, the first hypothesis proposed in this study is H1: Customer satisfaction is suspected to have a significant and positive effect on repurchase. Second hypothesis. First, the effect of brand equity on repurchase. One of the efforts to attract product consumers is by brand recognition so that the brand is also very important for the company. research by Pradipta et al (2016) and Sulistyowati et al., (2020) revealed that brand equity has a significant influence on purchasing decisions. Based on the description previously explained, the second hypothesis proposed in this study is H2: It is suspected that brand equity has a significant and positive effect on repurchase.

\section{Results and Discussion}

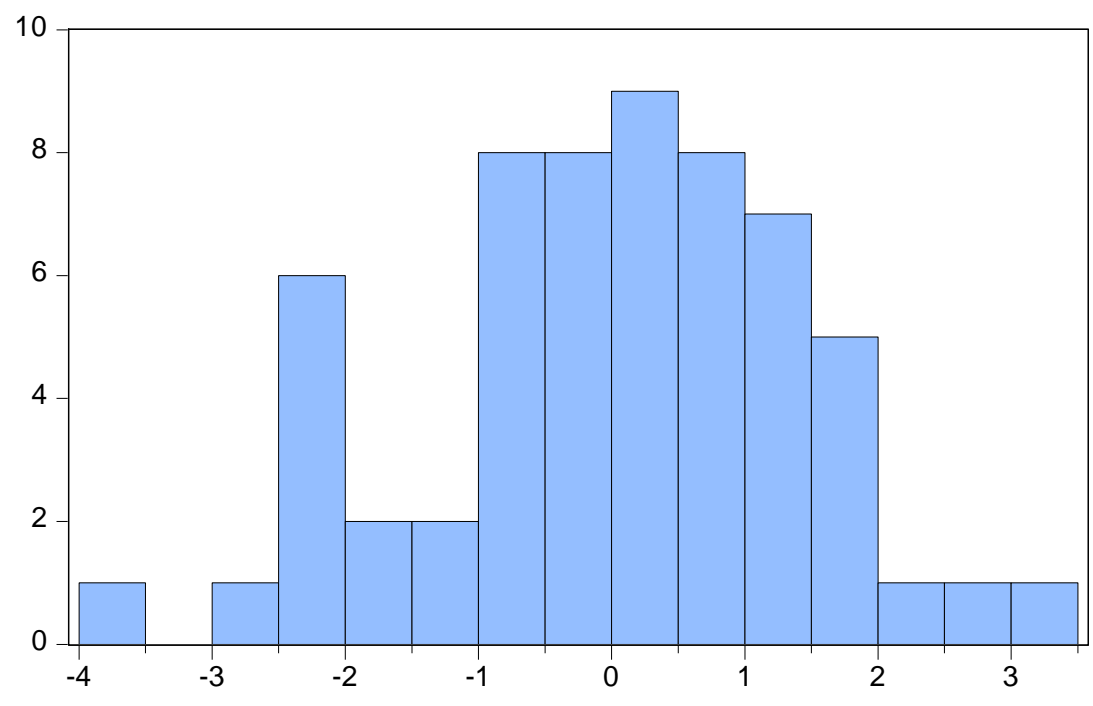

\begin{tabular}{|lr|}
\hline \multicolumn{2}{|l|}{ Series: Residuals } \\
Sample 1 60 \\
Observations & 60 \\
& \\
Mean & $9.16 \mathrm{e}-16$ \\
Median & 0.168132 \\
Maximum & 3.067214 \\
Minimum & -3.761095 \\
Std. Dev. & 1.431852 \\
Skewness & -0.312998 \\
Kurtosis & 2.770384 \\
& \\
Jarque-Bera & 1.111484 \\
Probability & 0.573646 \\
\hline
\end{tabular}

Figure 2. Jarque-Bera Normality Test Results

Source: Primary Data Analysis, 2021

The normality test is used to see whether two independent and dependent variables used in this study follow a normal distribution or not. Based on Figure 2, it can be seen that from results of normality test with jarque fallow value indicator of 0.5736 or with a percentage of $57.36 \%$ value is greater than $5 \%$ alpha value. This figure shows that data used in this study have passed normality test or data used are normally distributed. That way research data can be continued with classical assumption tests such as heteroscedasticity and multicollinearity tests. The following are results of heteroscedasticity test and multicollinearity test. 


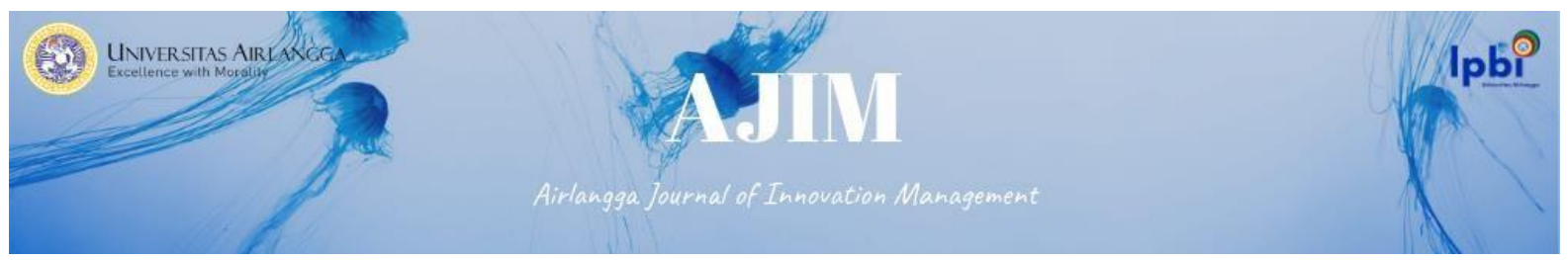

Table 1.

Heteroskedasticity Test: White

\begin{tabular}{llll}
\hline \hline F-statistic & 0.897447 & Prob. F(5,54) & 0.4895 \\
Obs*R-squared & 4.603298 & Prob. Chi-Square(5) & 0.4662 \\
Scaled explained SS & 3.677509 & Prob. Chi-Square(5) & 0.5967 \\
\hline \hline
\end{tabular}

Source: Primary Data Analysis, 2021

The heteroscedasticity test is one of classic assumption tests that must be done before data enters multiple regression analysis. The purpose of doing this test is to see if there are any similarities or inequalities experienced by variants of residuals from one observation to another. In this study, white test was used as a heteroscedasticity test. Based on table 1 , it can be seen that probability value of Obs * R-squared is greater than alpha value of $5 \%$, namely 0.4662 , so that this value also indicates that there is no heteroscedasticity problem so that variance is consistent. After data passes heteroscedasticity test, multicollinearity test will be continued which will be shown in Table 2 .

Table 2.

Multicolinearity Test

\begin{tabular}{cc}
\hline \hline Variable & VIF \\
\hline \hline X2 & 1.595876 \\
X1 & 1.595876 \\
\hline \hline
\end{tabular}

Source: Primary Data Analysis, 2021

The purpose of this test is to test model to find a correlation between the independent variables or not. One of indicators used in multicollinearity test is VIF value. If VIF value is less than 10, research data passes multicollinearity test. Based on table 2, it can be seen that VIF value of two independent variables used in this study (customer satisfaction and brand equity) has a value of less than 10 so it can be said that it passes the multicollinearity test.

Table 3.

Multiple Linear Analysis Results

\begin{tabular}{lccc}
\hline \multicolumn{1}{c}{ Variable } & Coefficient & $\begin{array}{c}\mathrm{t}- \\
\text { count }\end{array}$ & Sig. \\
\hline $\mathrm{C}$ & 2.0833 & 1.1244 & 0.2660 \\
$\mathrm{X} 1$ & $0.1401 * * *$ & 3.5950 & 0.0007 \\
$\mathrm{X} 2$ & $0.0858^{* *}$ & 3.8641 & 0.0317 \\
\hline Adjusted $\mathrm{R}^{2}$ & & & 0.3695 \\
\hline F Count & & & 8.2924 \\
\hline F sig. & & & 0.0000 \\
\hline
\end{tabular}

Source: Primary Data Analysis, 2021 


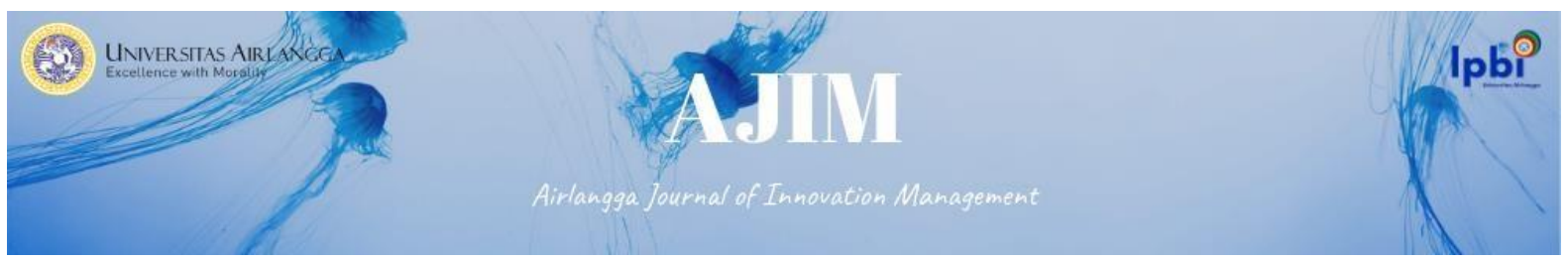

Based on table 3, we can see results of multiple linear regression analysis. Table 3 shows effect of X1 (customer satisfaction) and X2 (brand equity) on interest in repurchasing sugar. Table 3 shows adjusted $\mathrm{R}^{2}$ value of 0.3695 or a percentage of $36.95 \%$. This figure shows that variation of dependent variable can be explained by variation of independent variable, while remaining $63.05 \%$ is explained by other variables not included in model. If seen from value on F-test, it can be seen that significance value of $F$ test is 0.0000 and this value is less than alpha value of 0.05 , so it can be interpreted that together independent variables of customer satisfaction and brand equity have an effect on repurchase interest "Gulaku". If viewed from t-test of each independent variable, it can be seen that both of them have an effect on dependent variable. Variable X1 (customer satisfaction) has a significance value of 0.0007 so that value is less than alpha 0.05 , in other words that variable X1 (customer satisfaction) has an effect on repurchase interest. When viewed from coefficent value, an increase in customer satisfaction by 1 unit will increase interest in product repurchasing by consumers by 0.1401 units. Variable X2 (brand equity) has a significance value of 0.0317 so that value is less than alpha 0.05 . In other words, variable X2 (brand equity) has an effect on dependent variable on repurchase interest. If seen from coefficent value, an increase in brand equity by 1 unit will increase interest in product repurchase by consumers by 0.08 units.

Level of customer satisfaction with products purchased and consumed is a major issue that must be considered for company. Consumers who buy then feel satisfaction with products they buy and create a sense of joy and happiness, of course, will be willing to repurchases. Moreover, when there is competition between some of products in this study regarding Gulaku products with other sugar products, of course consumers will also compare the use of both so that according to consumers, Gulaku products provide excessive satisfaction. Of course, satisfying consumer needs is desire of every company. Apart from this, there is also a matter of brand equity which affects interest in repurchasing sugar. In case of this research, product "Gulaku" is actually a familiar brand in ears of consumers so that this product in terms of brand has won the trust of consumers. That way, without thinking, consumers will repurchase sugar with that brand. Implicitly, high brand equity will be able to increase customer satisfaction. This is certainly reflected in the brand equity indicator which is divided into several indicators such as superiority, superiority and brand memory loyalty.

These results are in line with research by Pradipta et al (2016) which states that simultaneously brand equity has a significant influence on purchasing decisions. This shows that the brand is the first consideration of consumers in making purchasing decisions, as well as showing the importance of brand equity for consumers to reduce unwanted purchases. This is also in the research of Sulistyowati et al (2020) which emphasizes that branding is something important and has an impact on consumer buying interest in a branded product that is already strong in the market and will beat products that are not well branded. The results of research from Imran (2018) show that there is a positive and significant influence between the influence of customer satisfaction on repurchase interest. Products produced in quality must meet customer desires so that customers get the satisfaction given after consuming the product so that consumers are happy and satisfied, this is what can increase customer buying interest repeatedly.

\section{Conclusion}

Based on research results, it can be concluded that interest in repurchasing sugar is influenced by two variables, namely customer satisfaction and brand equity. Consumer satisfaction with sugar can be seen from sense of pleasure and sense of being fulfilled by needs of consumers for purchase of sugar so that a sense of satisfaction appears from consumer. This has led to emergence of interest in re- 


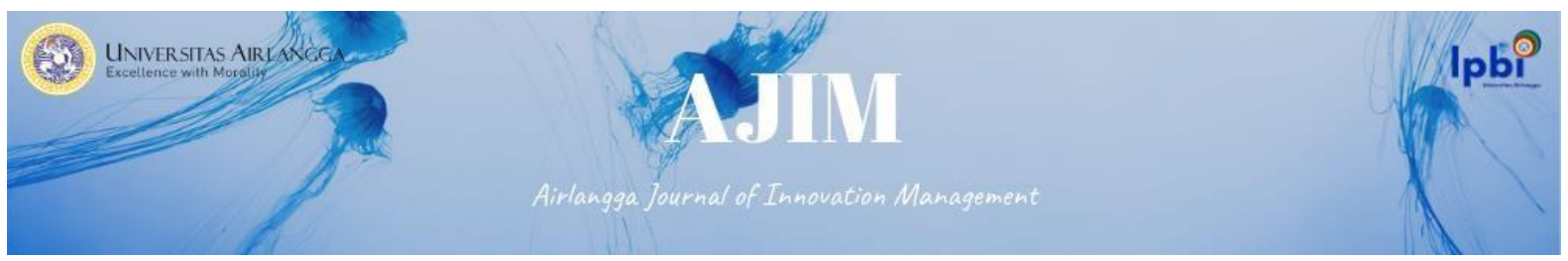

purchasing sugar with this brand. Brand equity also affects interest in repurchasing where consumer's trust in a particular brand makes consumers willing to repurchase product. Implicitly, high brand equity will be able to increase customer satisfaction. It is better if company management maintains quality of its products so that consumer satisfaction and trust in brand remains so that consumers are indirectly interested in making repeat purchases. Customer satisfaction variables that are able to influence customers to make product purchases, in this case sugar, must be maintained properly. Indicators of consumer satisfaction must also be maintained so that the product is always in accordance with consumer expectations. In addition, consumers get experience in consuming these products. Satisfied customers will make consumers believe in the product and repurchase the product. In this case, brand equity has its own impact on product purchase decisions by consumers. Sugar that has good brand equity will sell well in the market when compared to sugar brands that are less often seen or seen by consumers. For researchers who will conduct further research, it is better to add other variables so that it can be known what other factors can affect consumer repurchase.

\section{References}

Ardianto, Roesdian. (2013). Pengaruh kepuasan nasabah terhadap loyalitas nasabah yang di mediasi oleh kepercayaan nasabah pada bank BRI Syariah Surakarta. Skripsi. Unversitas Muhammadiyah Surakarta.

Awi, Y. L., \& Chaipoopirutana, S. (2014). A Study of Factors Affecting Consumer's Repurchase Intention toward XYZ Restaurant in Myanmar. International Conference on Trends in Economics, Humanities, and Management .

Casalo, LV., C. Falvian, dan M. Guinaliu. 2011. The Generation of Trust in the Online Service and Product Distribution: The case of Spanish Electronic Commerce. Journal of Electronic Commerce Research, Vol 12, No 3.

Dewati, R. WA Saputro. (2020). Persepsi Konsumen Terhadap Pembelian Produk Herbal Di Kabupaten Sukoharjo. Agrisaintifika Jurnal Ilmu-Ilmu Pertanian, 4 (2). 14-20. 145-152.

E Sulistyowati, T Wisudawati. WA Saputro. 2020. Faktor-Faktor Yang Mempengaruhi Keputusan Pembelian Gula Kristal Putih Di Daerah Istimewa Yogyakarta. Agrisaintifika Jurnal Ilmu-Ilmu Pertanian 4 (1). 14-20.

Farida, N. 2014. Analisis Model Kepuasan Terhadap Pembelian Ulang. Jurnal Dinamika Manajemen. 5 (2). 200-208

Fatona, S. 2010. Kualitas Jasa yang Mempengaruhi Loyalitas dan Relevansinya terhadap Kepuasan. Jurnal Dinamika Manajemen. 1 (1): 41-46.

Ferdinand, A. 2013. Metode Penelitian Manajemen. Semarang: UNDIP Press.

Halim, C., Dharmayati, D., \& Brahmana, M. (2014). Pengaruh Brand Identity Terhadap Timbulnya Brand Preference dan Repurchase Intention pada Merek Toyota. Jurnal Manajemen Petra 2, 1, $1-11$.

Imran, MIA. Pengaruh Kepuasan Pelanggan Terhadap Minat Beli Ulang Makanan Di Rumah Makan Ayam Bakar Wong Solo Alauddin Kota Makassar. Jurnal Profitability Fakultas Ekonomi Dan Bisnis. 2 (1). 50-64

Joseph, O., Onyemachi, Lilian, K.-O., \& Okpara, M. (2012). Analysis of the Determinants of Repurchase Intention of Soap Products of an Agribusiness Firm on Abia State, Nigeria. Journal of Economics and Sustainable Development , 3 . 


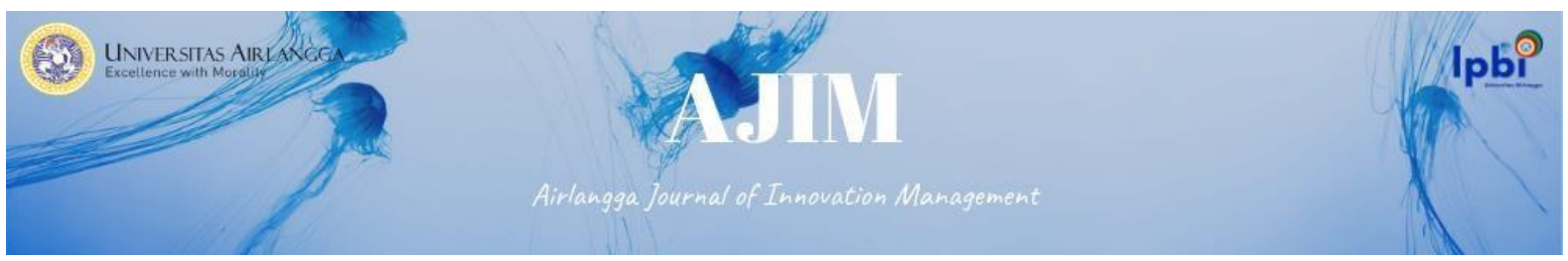

Katniati, L. E Sulistyowati. Salamah, U. WA Saputro. 2021. Strategi Pemasaran Industri Ukir (Rancak Gamelan) Desa Karangasem, Manyaran Kab. Wonogiri Sebagai Desa Sentra Industri Kayu. Journal Economics and Management (JECMA). 1 (2). 10-17.

Kotler, Philip \& Kevin L. Keller. (2009). Manajemen pemasaran jilid 1, edisi Ketiga belas, Terjemahan Bob Sabran. Jakarta: Erlangga

Kurniawati, M. Sidiq, AN. (2020). Inovasi Perancangan Insentif Untuk Meningkatkan Kinerja Pada Perusahaan Cleaning Service Online. AJIM: Airlangga Journal Innovation Management. 1 (2). $143-152$

Kusdyah, I. (2012). Persepsi Harga, Persepsi Merk, Persepsi Nilai, dan Keinginan Pembelian Ulang Jasa Clinic Kesehatan (Studi Kasus Erha Clinic Surabaya). 7.

Pradipta, D. Hidayat, K. Sunarti. 2016. Pengaruh Brand Equity Terhadap Keputusan Pembelian. Jurnal Administrasi Bisnis (JAB). 34 (1). 138-147

Pupuani, N. W., \& Sulistyawati, E. (2013). Pengaruh Bauran Pemasaran Terhadap Kepuasan Konsumen dan Perilaku Pembelian Ulang (Studi Kasus pada Produk Pasta Gigi Merek Pepsodent di Kota Denpasar). E-Jurnal Management , 2.

Putri, LH. (2016). Faktor-Faktor Yang Mempengaruhi Minat Pembelian Ulang Konsumen Terhadap Produk Naget Delicy. PERFORMA: Jurnal Manajemen dan Start-Up Bisnis. 1 (2). 162-170

Panjaitan, JE. Yulianti, AL. 2016. Pengaruh Kualitas Pelayanan Terhadap Kepuasan Pelanggan Pada Jne Cabang Bandung. DeReMa Jurnal Manajemen. 11 (2). 265-289.

Ristanto, A. Rakhmawati, I. T Wisudawati. WA Saputro. 2021. Analisis Pengaruh Marketing Mix Berbasis Media Sosial Untuk Meningkatkan Omzet Pada Ethikopia Coffe. Prosiding Seminar Nasional Aplikasi Sains \& Teknologi (SNAST). 46-49.

Solichin, A. Amalia, DAR. Lily Katniaty. T Wisudawati. E Sulistyowati. WA, Saputro. 2021. Pengaruh E-Wom Dan Risk Perception Terhadap Keputusan Berkunjung Wisatawan. Journal Economics and Management (JECMA). 1 (2). 1-9.

Tjiptono, F. 2011. Manajemen dan Strategi Merek. Yogyakarta: ANDI Ofset.

T Wisudawati, WA Saputro. (2020). Pengukuran Tingkat Kepuasan Konsumen Terhadap Kualitas Pelayanan Ethikopia Coffee Di Kabupaten Sleman. JRSI Jurnal Rekayasa Sistem Industri. 5 (2). 97-105

T Wisudawati. Rizalmi, SR. 2020. Analisis Metode Marketing Mix 7P Sebagai Strategi Pemasaran Produk Daur Ulang. Journal Science Innovation and Technology (SINTECH). 1 (1). 26-29

Utomo, WP. T Kurniawan. A Fauzi. T Wisudawati. E Sulistyowati. WA Saputro. 2021. Penentuan Strategi Pengembangan Agribisnis Jahe di Karesidenan Surakarta Pada Masa Pandemi Covid19. Paradigma Agribisnis. 3 (2). 32-44

Wen, Chao 2011. An integrated model for customer online repurchase intention, journal of Computer Information System. 